\title{
New record and range extension of Bradybaena similaris (Férussac, 1822) (Gastropoda, Camaenidae) in Argentina
}

\author{
Enzo N. Serniotti ${ }^{1,2}$, Leila B. Guzmán ${ }^{1,2}$, Roberto E. Vogler ${ }^{1,2}$, Alejandra Rumi², Juana G. Peso ${ }^{1}$, \\ Ariel A. Beltramino ${ }^{1,2}$
}

1 Grupo de Investigación en Genética de Moluscos, Instituto de Biología Subtropical, CONICET - Universidad Nacional de Misiones, Rivadavia 2370, Posadas, Misiones, N3300LDX, Argentina. 2 División Zoología Invertebrados, Facultad de Ciencias Naturales y Museo, Universidad Nacional de La Plata, CONICET, Paseo del Bosque s/n, La Plata, Buenos Aires, B1900FWA, Argentina.

Corresponding authors: Enzo N. Serniotti, serniottienzo@gmail.com enzoserniotti@fceqyn.unam.edu.ar; Ariel A. Beltramino, beltraminoariel@ hotmail.com

\begin{abstract}
The Asian tramp snail Bradybaena similaris (Férussac, 1822) is an exotic mollusk native to Southeast Asia. The species has been catalogued as invasive in several countries and is important to human health, animal health, and agriculture. We report for the first time the presence of B. similaris in Córdoba Province, Argentina, extending the southern distribution of the species in this country and in South America. Anatomical, conchological, and molecular information obtained here represent the second contribution for this species in Argentina.
\end{abstract}

\section{Keywords}

16S-rRNA, Asian tramp snail, exotic land snail, invasive species, reproductive system, shell morphotypes, South America.

Academic editor: Rodrigo B. Salvador | Received 1 November 2019 | Accepted 16 December 2019 | Published 21 February 2020

Citation: Serniotti EN, Guzmán LB, Vogler RE, Rumi A, Peso JG, Beltramino AA (2020) New record and range extension of Bradybaena similaris (Férussac, 1822) (Gastropoda, Camaenidae) in Argentina. Check List 16 (1): 211-217. https://doi.org/10.15560/16.1.211

\section{Introduction}

The genus Bradybaena Beck, 1837 is rather speciose with more than 100 species only in China (De Winter et al. 2009; Wu and Asami 2018). Although the native range of this genus is Southeast Asia, the Asian tramp snail, Bradybaena similaris (Férussac, 1822), has reached all continents except Antarctica probably due to the plant trade, which is considered the main cause of its introduction (Carvalho et al. 2008; Schileyko 2011). This species has invaded many countries; it is well known to cause damage to several crop and ornamental species and to host parasites of medical and veterinary importance (Alicata 1940; Cowie et al. 2009; Robinson and Hollingsworth 2009; Capinera and White 2011; Matamoros 2014). In particular, this species has been found to be the intermediate host of the digenetic trematodes Postharmostomum gallinum Witenberg, 1923, a cecal fluke of poultry, and Eurytrema coelomaticum (Giard \& Billet, 1892), a pancreatic fluke of bovine, caprine, and porcine animals (Amato and Bezerra 1989; Araujo 1989). Additionally, individuals of $B$. similaris can serve as the intermediate hosts of human parasitic nematodes such as Angiostrongylus costaricensis Morera \& Céspedes, 1971, the cause of abdominal angiostrongyliasis, and the rat lungworm, 
Angiostrongylus cantonensis (Chen, 1935), the etiologic agent of eosinophilic meningitis (Caldeira et al. 2007; Ohlweiler et al. 2010; Cowie 2013). Bradybaena similaris exhibits four shell morphotypes based on ground color of periostracum and banding pattern of the ostracum and periostracum: dark brown and banded, dark brown and unbanded, light brown and banded, and light brown and unbanded (Komai and Emura 1955; Asami and Asami 2008). Anatomically, the reproductive system of $B$. similaris is broadly characterized by the presence of two mucous glands inserting on a dart sac with a single dart, and particularly by having about six pilasters with rhomboidal pustules on the inner penis surface (Wu 2004; Wu and Asami 2018; Serniotti et al. 2019). Together with molecular markers, the latter feature is also the most important character to discriminate $B$. similaris from the sibling species $B$. pellucida Kuroda $\&$ Habe, 1953, which is difficult to distinguish by shell color and gross morphology of the reproductive system (Asami and Asami 2008; Seki et al. 2008).

In South America, specimens of $B$. similaris were first reported by d'Orbigny $(1835,1838)$ on the Brazilian coast and by Doering (1875) in Argentina from Buenos Aires city, where they did not become established (Miquel et al. 2007; Virgillito and Miquel 2013). In the mid-1950s, the species was recorded in Tucumán and Misiones provinces without further information other than the general statement as occurring in those provinces (Drahg 1999; Miquel et al. 2007; Gutiérrez Gregoric et al. 2013a; Virgillito and Miquel 2013). Recently, Serniotti et al. (2019) reported eight new occurrences of $B$. similaris in the Misiones Province and the southernmost record for the species in South America from a locality of Entre Ríos Province, providing the first molecular and anatomical data for the species in Argentina.

In this work, we report for the first time the presence of B. similaris in Córdoba Province, central Argentina, extending the southern distribution range of the species in this country, as well as in South America. The molecular and anatomical data obtained here represent the first information of this species from Córdoba Province and the second one for Argentina.

\section{Methods}

Specimens of Bradybaena similaris were collected by hand in a residential garden from the locality of Río Tercero, Córdoba Province, Argentina. Individuals were relaxed in water with menthol crystals for $4-10 \mathrm{~h}$, then immersed in hot water $\left(80^{\circ} \mathrm{C}\right)$ and finally preserved in 96 $\%$ ethanol. Voucher material was deposited in the malacological collection of the Instituto de Biología Subtropical (IBS-Ma), CONICET-UNaM, Misiones Province, Argentina. For the morpho-anatomical studies, shells of four adult individuals (IBS-Ma 385-2, 385-3, 385-5, 385-7) were separated from the soft parts, cleaned in an ultrasonic bath Codyson CD4810 and photographed in dorsal-lateral, apertural, apical and umbilical views.
The soft parts were dissected using a Labomed Luxeo 4D stereomicroscope for the study of the reproductive system. Genomic DNA was isolated from a portion of pedal muscle of the same morpho-anatomical analyzed specimens by means of a cetyltrimethylammonium bromide protocol (Beltramino et al. 2018). Partial sequences of the 16S-rRNA mitochondrial marker were amplified by polymerase chain reaction (PCR) using the primers 16SF-104 and 16SR-472 (Ramirez and Ramírez 2010). PCR reaction master mix and thermal profile were performed as in Serniotti et al. (2019). Due to the co-amplification of nonspecific fragments, PCR products were purified from $1.5 \%(\mathrm{w} / \mathrm{v})$ agarose gel using an ADN PuriPrep-GP Kit (Inbio Highway, Argentina), and bidirectionally sequenced by Macrogen Inc. (Seoul, Korea). The resulting sequences were trimmed to remove the primers and assembled using BIOEDIT v. 7.2 .5 (Hall 1999). To confirm the identity of the species, consensus sequences were compared with reference sequences in GenBank through BLASTn algorithm (Altschul et al. 1990). Partial DNA sequences of the 16S-rRNA marker were deposited in GenBank under the accession numbers MN158200 to MN158203.

\section{Results}

\section{Taxonomic account}

Gastropoda Cuvier, 1795

Stylommatophora A. Schmidt, 1855

Camaenidae Pilsbry, 1895

Bradybaena H. Beck, 1837

\section{Bradybaena similaris (Férussac, 1822)}

New record. Argentina: Córdoba Province: Río Tercero city $\left(32^{\circ} 09.83^{\prime} \mathrm{S}, 064^{\circ} 06.6^{\prime} \mathrm{W} ; 377 \mathrm{~m}\right.$ a.s.1.), collected by D. Sequeira, P. Depetris and R.E. Vogler, 4 January 2019 (81 specimens and 10 dried shells, IBS-Ma 385) (Table 1, Fig. 1).

Identification. Snails were firstly identified as $B$. similaris based on the size and color of the shells, which were found to be light brown banded and unbanded (Fig. 2A, B). Morphology of the reproductive system was consistent with those described by Araujo (1989), Picoral and Thomé (1989), and Wu (2004) and fits particularly well with that shown by Serniotti et al. (2019) for Argentine specimens (Fig. 2C). All individuals analyzed exhibited the inner penial wall with six to eight branched and crenulated pilasters anastomosing towards the atrium, a diagnostic feature for the species and the only character capable of discriminating B. similaris from B. pellucida (Fig. 2D). The length of the amplified fragments was 265-266 bp for all individuals. When compared to GenBank sequences, 16S-rRNA sequences obtained here showed top coverage and high similarity scores of $95-100 \%$ with specimens of $B$. similaris (Table 2). 
Table 1. Records of Bradybaena similaris in Argentina. Shell morphotypes and genetic data are provided if available. IBS-Ma: malacological collection of the Instituto de Biología Subtropical (CONICET-UNaM), Misiones, Argentina. MACN-In: malacological collection at Museo Argentino de Ciencias Naturales Bernardino Rivadavia, Buenos Aires, Argentina. IFML: malacological collection at Instituto Fundación Miguel Lillo, Tucumán, Argentina. LB: light brown and banded. LU: light brown and unbanded.

\begin{tabular}{|c|c|c|c|c|c|c|c|c|}
\hline No. & Location & Voucher \# & Latitude & Longitude & Habitat & Morph & GenBank \# & References \\
\hline 1 & Río Tercero city, Córdoba & IBS-Ma 385-2 & $32^{\circ} 09.83^{\prime} S$ & $064^{\circ} 06.6^{\prime} \mathrm{W}$ & Residential garden & LB & MN158200 & Present study \\
\hline 2 & Río Tercero city, Córdoba & IBS-Ma 385-3 & $32^{\circ} 09.83^{\prime} \mathrm{S}$ & $064^{\circ} 06.6^{\prime} \mathrm{W}$ & Residential garden & LB & MN158201 & Present study \\
\hline 3 & Río Tercero city, Córdoba & IBS-Ma 385-5 & $32^{\circ} 09.83^{\prime} S$ & $064^{\circ} 06.6^{\prime} \mathrm{W}$ & Residential garden & LB & MN158202 & Present study \\
\hline 4 & Río Tercero city, Córdoba & IBS-Ma 385-7 & $32^{\circ} 09.83^{\prime} S$ & $064^{\circ} 06.6^{\prime} \mathrm{W}$ & Residential garden & LU & MN158203 & Present study \\
\hline 5 & Eldorado, Misiones & IBS-Ma 165-7 & $26^{\circ} 24.27^{\prime} S$ & $054^{\circ} 35.65^{\prime} \mathrm{W}$ & Residential garden & LU & MH428043 & Serniotti et al. 2019 \\
\hline 6 & Salto Capioví, Misiones & IBS-Ma 247-1 & $26^{\circ} 55.48^{\prime} \mathrm{S}$ & $055^{\circ} 03.72^{\prime} \mathrm{W}$ & $\begin{array}{l}\text { Waterfall environment } \\
\text { in urban area }\end{array}$ & LU & MH428046 & Serniotti et al. 2019 \\
\hline 7 & Posadas, Misiones & IBS-Ma 122-3 & $27^{\circ} 21.54^{\prime} S$ & $055^{\circ} 54.2^{\prime} \mathrm{W}$ & Residential garden & LU & MH428041 & Serniotti et al. 2019 \\
\hline 8 & Apóstoles, Misiones & IBS-Ma 253-3 & $27^{\circ} 55.18^{\prime} \mathrm{S}$ & $055^{\circ} 43.48^{\prime} \mathrm{W}$ & $\begin{array}{l}\text { Close to agricultural } \\
\text { plantations }\end{array}$ & LU & MH428047 & Serniotti et al. 2019 \\
\hline 9 & San Javier, Misiones & IBS-Ma 242-2 & $27^{\circ} 52.13^{\prime} S$ & $055^{\circ} 08.52^{\prime} \mathrm{W}$ & Residential garden & LU & MH428044 & Serniotti et al. 2019 \\
\hline 10 & Salto Las Mujeres, Misiones & IBS-Ma 243-1 & $27^{\circ} 43.66^{\prime} S$ & $055^{\circ} 10.13^{\prime} \mathrm{W}$ & $\begin{array}{l}\text { Waterfall environment } \\
\text { in rural area }\end{array}$ & LB & MH428045 & Serniotti et al. 2019 \\
\hline 11 & Oberá, Misiones & IBS-Ma 102-2 & $27^{\circ} 28.54^{\prime} S$ & $055^{\circ} 06.12^{\prime} \mathrm{W}$ & Residential garden & LU & MH428040 & Serniotti et al. 2019 \\
\hline 12 & San Vicente, Misiones & IBS-Ma 096-1 & $26^{\circ} 59.98^{\prime} S$ & $054^{\circ} 29.43^{\prime} \mathrm{W}$ & Residential garden & LU & MH428039 & Serniotti et al. 2019 \\
\hline 13 & San Antonio, Misiones & MACN-In 30444 & $26^{\circ} 04^{\prime} S$ & $053^{\circ} 44^{\prime} \mathrm{W}$ & - & - & - & $\begin{array}{l}\text { Miquel et al. 2007; } \\
\text { Virgillito and Miquel } 2013\end{array}$ \\
\hline 14 & San Ignacio, Misiones & MACN-In 35896 & $27^{\circ} 15^{\prime} \mathrm{S}$ & $055^{\circ} 32^{\prime} \mathrm{W}$ & - & - & - & Virgillito and Miquel 2013 \\
\hline 15 & Villaguay, Entre Ríos & IBS-Ma 142-1 & $31^{\circ} 52.22^{\prime} \mathrm{S}$ & $059^{\circ} 01.84^{\prime} \mathrm{W}$ & Residential garden & LU & MH428042 & Serniotti et al. 2019 \\
\hline 16 & San Miguel de Tucumán, Tucumán & IFML 14990 & $26^{\circ} 48.6^{\prime} \mathrm{S}$ & $065^{\circ} 14.81^{\prime} \mathrm{W}$ & Plant nursery & - & - & $\begin{array}{l}\text { Virgillito 2012; } \\
\text { Virgillito and Miquel } 2013\end{array}$ \\
\hline 17 & Tafí Viejo, Tucumán & IFML 15419 & $26^{\circ} 44^{\prime} S$ & $065^{\circ} 16^{\prime} \mathrm{W}$ & Residential garden & - & - & $\begin{array}{l}\text { Virgillito 2012; } \\
\text { Virgillito and Miquel } 2013\end{array}$ \\
\hline
\end{tabular}

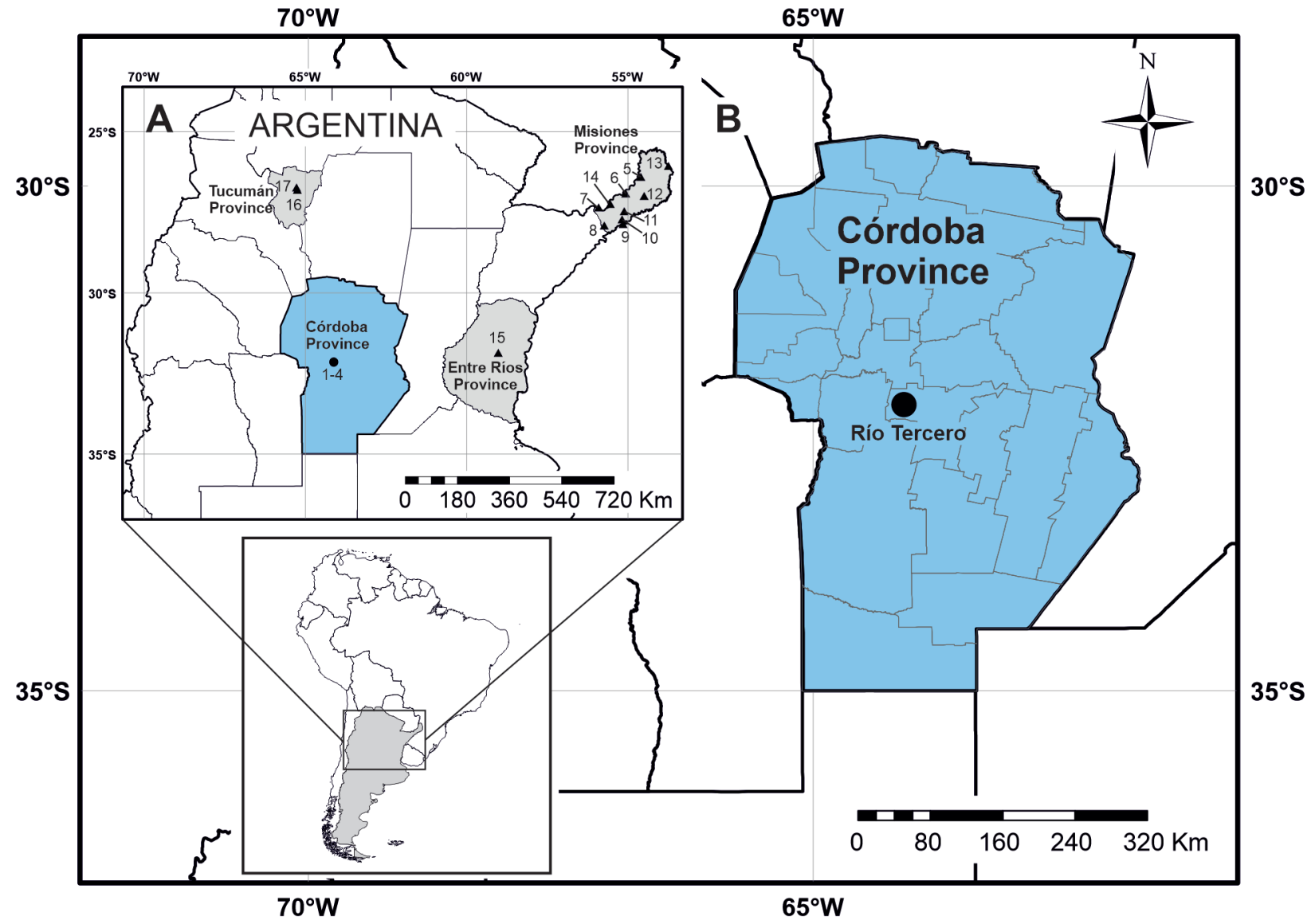

Figure 1. Distribution map of the exotic land snail Bradybaena similaris. A. Locality records of the species in Argentina. B. Detail of the new record in Córdoba Province. Locations indicated with triangles correspond to literature records and the circles correspond to the new locality where the specimens of B. similaris were found. Location numbers correspond to the numbers in Table 1. 
Table 2. Top five results of the BLASTn search for each haplotype of Bradybaena similaris found in this study.

\begin{tabular}{|c|c|c|c|c|c|c|c|}
\hline Sequence accesion \# & Most significant alignment & GenBank \# & E-value & Coverage (\%) & Identity (\%) & Geographical origin & References \\
\hline \multirow{5}{*}{$\begin{array}{l}\text { MN158200 } \\
\text { (266 bp) }\end{array}$} & B. similaris & MH428047 & $8 e-132$ & 100 & 100 & Misiones, Argentina & Serniotti et al. 2019 \\
\hline & B. similaris & MH428046 & $8 e-132$ & 100 & 100 & Misiones, Argentina & Serniotti et al. 2019 \\
\hline & B. similaris & MH428045 & $8 e-132$ & 100 & 100 & Misiones, Argentina & Serniotti et al. 2019 \\
\hline & B. similaris & MH428044 & $8 e-132$ & 100 & 100 & Misiones, Argentina & Serniotti et al. 2019 \\
\hline & B. similaris & MH428043 & $8 \mathrm{e}-132$ & 100 & 100 & Misiones, Argentina & Serniotti et al. 2019 \\
\hline \multirow{5}{*}{$\begin{array}{l}\text { MN158201 } \\
\text { MN158202 } \\
\text { MN158203 } \\
\text { (265 bp) }\end{array}$} & B. similaris & HQ245444 & 1e-117 & 100 & 96.23 & - & $\begin{array}{l}\text { Köhler and } \\
\text { Criscione } 2013\end{array}$ \\
\hline & B. similaris & GQ851164 & 1e-117 & 100 & 96.23 & $\begin{array}{l}\text { Sabah, } \\
\text { Malaysia }\end{array}$ & Hugall and Stanisic 2011 \\
\hline & B. similaris & GQ851001 & $2 e-115$ & 100 & 95.86 & $\begin{array}{l}\text { Queensland, } \\
\text { Australia }\end{array}$ & Hugall and Stanisic 2011 \\
\hline & B. similaris & KF247037 & $6 e-115$ & 100 & 95.47 & $\begin{array}{l}\text { Rio Grande do Sul, } \\
\text { Brazil }\end{array}$ & Sei et al. 2017 \\
\hline & B. similaris & MH428047 & 1e-111 & 100 & 94.74 & Misiones, Argentina & Serniotti et al. 2019 \\
\hline
\end{tabular}

\section{Discussion}

In this work we report a new record of Bradybaena similaris in Argentina, the first one of the species from Córdoba Province. This new locality record expands the southern distribution of B. similaris from the previous nearest records in Argentina, which are located at about $480 \mathrm{~km}$ northeast on the Entre Ríos Province and $600 \mathrm{~km}$ northwest on the Tucumán Province. With reference to Serniotti et al. (2019), specimens found in this study also constitute the new southernmost record of South America. This finding indicates the species is more widespread than previously thought and suggests it is spreading rapidly through the country. On the other hand, residents of the new locality where $B$. similaris was found reported that these snails have been present in Río Tercero city since for about 10 years, which suggests the species is already established and reproducing successfully. During this time, $B$. similaris could have spread to nearby cities and towns, although the species has not been documented in recent studies on invasive exotic mollusk species from Argentina, and particularly from Córdoba Province (Rumi et al. 2010; Gordillo et al. 2013; Reyna et al. 2018). Further surveys are required to gain insights into the distribution of the species in this area.

Specimens of B. similaris were found in an urban habitat, specifically on pot plants located on a residential garden. According to the literature, this is the habitat where populations of $B$. similaris usually live and in turn one of the most common introduction vectors for terrestrial mollusk species (Cowie and Robinson 2003; Gutiérrez Gregoric et al. 2013b, 2013c). When consulted, residents stated that it is common practice to bring ornamental plants and/or organic compost from Chaco, Formosa, and Misiones provinces, pointing out these regions as probable sources of $B$. similaris. However, due to the lack of records of the species in Chaco and Formosa provinces, Misiones becomes the most probable geographic source for the introduction in Córdoba Province. In this sense, additional studies comprising more populations from different provinces are needed to elucidate the introduction history of $B$. similaris in Córdoba Province and dispersal routes in Argentina.
The new record from Córdoba Province, as well as the previous southernmost one from Entre Ríos Province, were both found in temperate climates. Together with the evidence gathered on cold resistance of B. similaris (Komai and Emura 1955; Asami and Asami 2008), this finding reinforces the hypothesis that temperature may be limiting factor for spread of this species (Serniotti et al. 2019). Nonetheless, studies using bioclimatic modeling are needed to effectively assess those areas of the country where the species could invade or where the species is already present but not detected.

Four shell morphotypes of B. similaris have been described so far and are either lighter or darker shells with or without a single chestnut spiral band. Since Komai and Emura (1955), various authors have referred to the lighter shells as yellowish and to the darker ones as brownish (e.g. Neck 1976; Ohlweiler et al. 2010; Capinera and White 2011; Serniotti et al. 2019). However, Asami and Asami (2008) stated that there is no yellow pigmentation either in the body or the shell of this species (e.g. as it is in the sibling species B. pellucida) and proposed a more accurate way to refer to the shell morphotypes of B. similaris based on ground color of periostracum and banding pattern of the ostracum and periostracum. Following Asami and Asami (2008), in this study the lighter shells are referred to as light brown and the darker ones are referred to as dark brown. As found by Serniotti et al. (2019) for Argentine specimens from Misiones and Entre Ríos provinces, the two lighter shell morphotypes were found among the 91 shells analyzed here. Although all the shells were found to be light brown, we suggest there is some variation in the ground color of shells classified as "light" and "dark"; this hypothesis needs further research.

Anatomically, the individuals analyzed in this study exhibited the gross morphology and inner penial structure as defined for B. similaris (see Araujo 1989; Picoral and Thomé 1989; Wu 2004; Serniotti et al. 2019). Specimens dissected here were different from those of $B$. pellucida in having long, thick, anastomosed pilasters running from near the atrium to the epiphallus instead of short, neither branched nor crenulated pilasters 


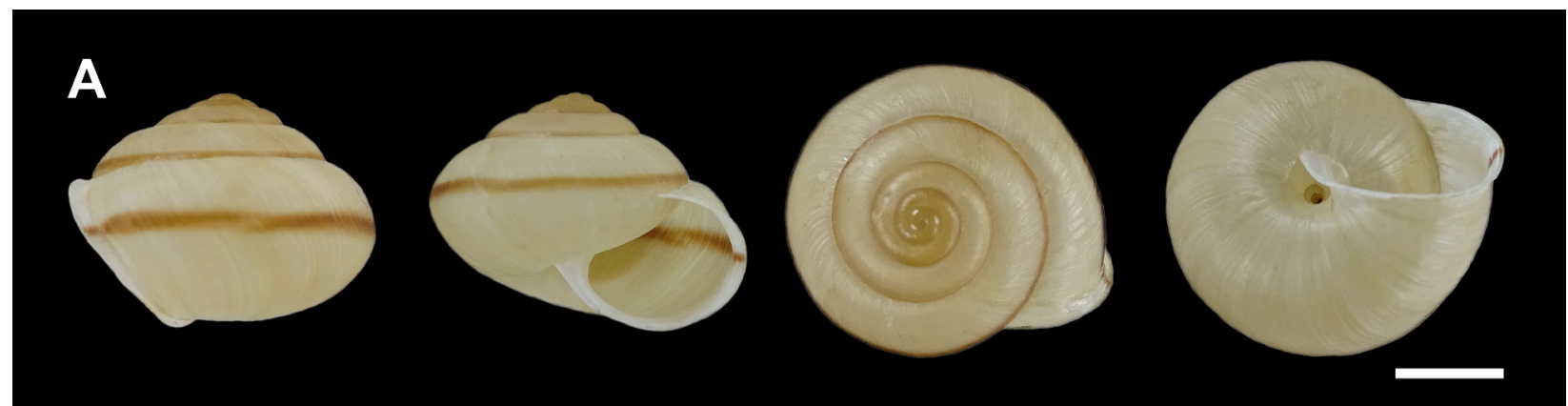

\section{B}
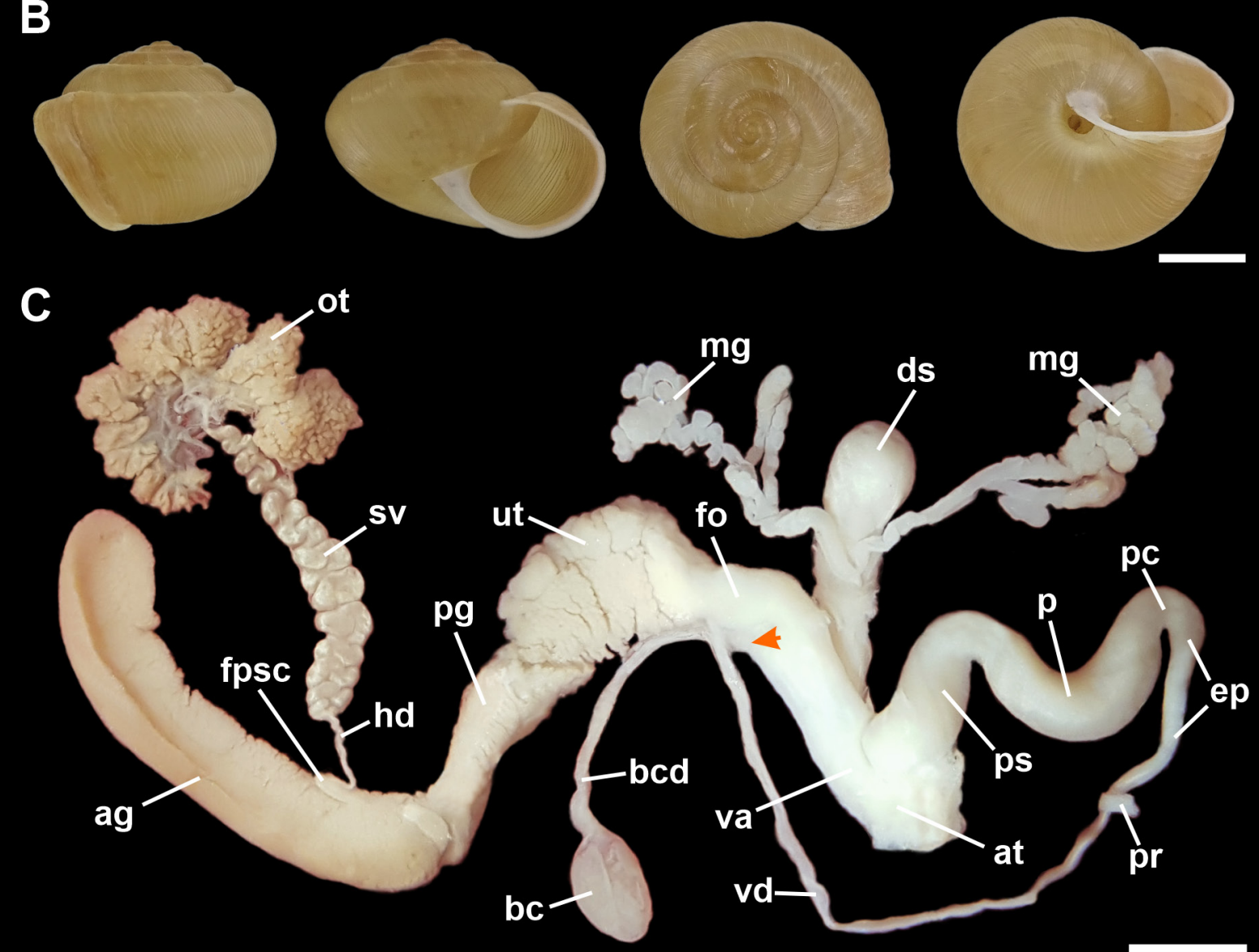

ds $\quad \mathrm{mg}$
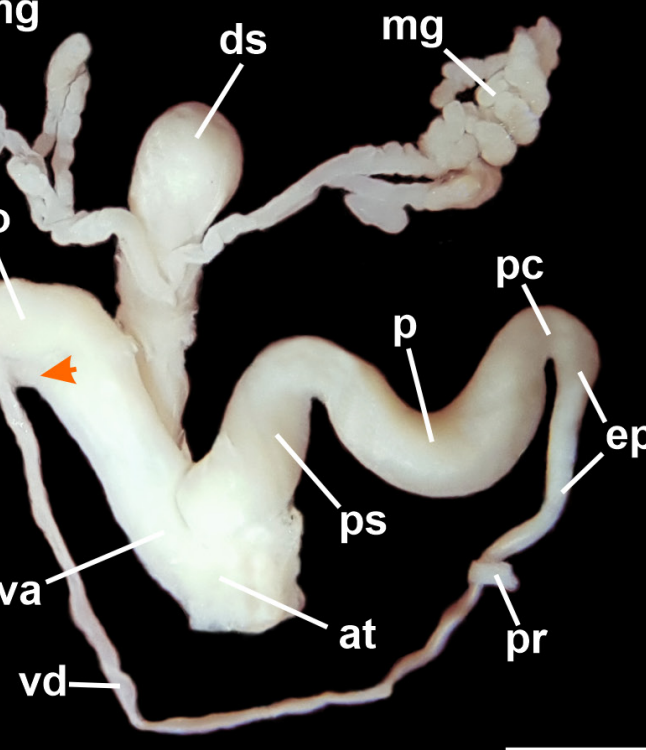

D

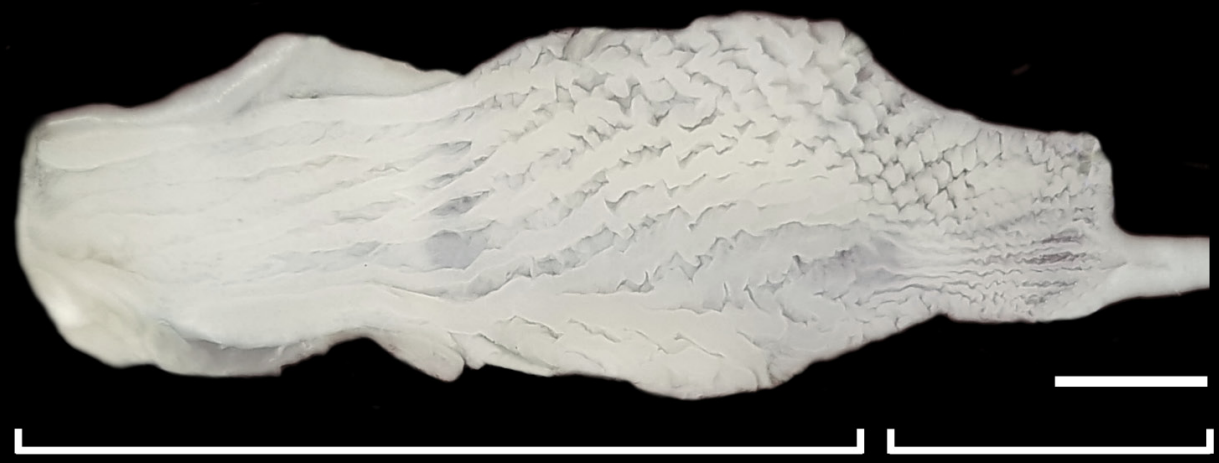

p

Figure 2. Shells and reproductive system of Bradybaena similaris from Córdoba Province, Argentina. A. Light brown and banded shell morphotype. Scale bar $=5 \mathrm{~mm}$. B. Light brown and unbanded shell morphotype. Scale bar $=5 \mathrm{~mm}$. C. General view of the reproductive system. The arrow indicates the insertion of the bursa copulatrix duct into the vagina. Scale bar $=2.5 \mathrm{~mm}$. D. Detail of the inner penial wall. Scale bar $=1.25 \mathrm{~mm}$. Abbreviations: ag, albumen gland; at, atrium; bc, bursa copulatrix; bcd, bursa copulatrix duct; ds, dart sac; ep, epiphallus; fo, free oviduct; fpsc, fertilization pouch-spermathecal complex; hd, hermaphroditic duct; mg, mucous glands; ot, ovotestis; p, penis; pc, penial constriction; pg, prostate gland; pr, penial retractor muscle; ps, penial sheath; sv, seminal vesicle; ut, uterus; va, vagina; $\mathrm{vd}$, vas deferens. 
occupying one-third of the penial wall. Additionally, individuals from Córdoba Province showed fine, very compressed, and crenulated pilasters on the inner wall of epiphallus rather than thin and partly crenulated ones as in B. pellucida (Seki et al. 2008).

Molecularly, two different haplotypes were found among the sequences analyzed for the specimens from Córdoba Province. One of these haplotypes was already reported by Serniotti et al. (2019) for eight localities of Misiones Province and one locality from Entre Ríos Province, suggesting the carriers could have been introduced from this region. The other haplotype detected here is a novel one and was found in three of the four analyzed specimens. A major study with more sequences from Tucumán, Misiones, Entre Ríos, and Córdoba provinces is needed to clarify the invasion pathways and number of introductions of B. similaris in Argentina.

\section{Acknowledgements}

This study was financially supported by Facultad de Ciencias Exactas, Químicas y Naturales - Universidad Nacional de Misiones (Proyecto de Investigación 16Q634), Agencia Nacional de Promoción Científica y Tecnológica (PICT-2017-3961 - Préstamo BID) and Facultad de Ciencias Naturales y Museo - Universidad Nacional de La Plata (Proyecto N870). We thank Dr Gonzalo Collado and an anonymous reviewer for the detailed suggestion and corrections made during the peer-review process, as well as Dr Rodrigo Brincalepe Salvador and Robert Forsyth for the constructive comments which greatly improved the manuscript.

\section{Authors' Contributions}

ENS and AAB conceived the research question. ENS, LBG, REV, AR, and JGP collected data and prepared voucher materials. ENS and LBG performed molecular and morpho-anatomical analyses and confirmed the taxonomic identity of specimens. LBG took all the photographs. ENS, LBG, REV, and AAB wrote the first draft of the manuscript. All authors reviewed the final version of the manuscript.

\section{References}

Alicata JE (1940) The life cycle of Postharmostomum gallinum, the cecal fluke of poultry. The Journal of Parasitology 26: 135-143. https://doi.org/10.2307/3272380

Altschul SF, Gish W, Miller W, Myers EW, Lipman DJ (1990) Basic Local Alignment Search Tool. Journal of Molecular Biology 215: 403-410. https://doi.org/10.1016/S0022-2836(05)80360-2

Amato SB, Bezerra JCB (1989) Parasitismo natural de Bradybaena similaris (Férussac, 1821) por Postharmostomum gallinum Witenberg, 1923. Memórias do Instituto Oswaldo Cruz 84: 75-79. https:// doi.org/10.1590/S0074-02761989000100014

Araujo JLB (1989) Moluscos de importância econômica no Brasil. I. Xanthonychidae: Bradybaena similaris (Férussac, 1821). (Mollusca, Gastropoda, Pulmonata, Stylommatophora). Revista
Brasileira de Zoologia 6: 583-592. https://doi.org/10.1590/S010181751989000400001

Asami T, Asami N (2008) Maintenance mechanism of a supergene for shell colour polymorphism in the terrestrial pulmonate Bradybaena similaris. Basteria 72: 119-127.

Beltramino AA, Vogler RE, Rumi A, Guzmán LB, Martín SM, Peso JG (2018) The exotic jumping snail Ovachlamys fulgens (Gude, 1900) (Gastropoda: Helicarionidae) in urban areas of the UpperParaná Atlantic Forest. Anais da Academia Brasileira de Ciências 90: 1591-1603. https://doi.org/10.1590/0001-3765201820170766

Caldeira RL, Mendonça CLGF, Goveia CO, Lenzi HL, Graeff-Teixeira C, Lima WS, Mota EM, Pecora IL, Medeiros AMZ, Carvalho OS (2007) First record of molluscs naturally infected with Angiostrongylus cantonensis (Chen, 1935) (Nematoda: Metastrongylidae) in Brazil. Memórias do Instituto Oswaldo Cruz 102: 887-889. https://doi.org/10.1590/S0074-02762007000700018

Capinera JL, White J (2011) Terrestrial snails affecting plants in Florida. Publication number EENY-497. Department of Entomology, University of Florida, Gainesville, $12 \mathrm{pp}$.

Carvalho CM, Bessa ECA, D'Ávila S (2008) Life history strategy of Bradybaena similaris (Férussac, 1821) (Mollusca, Pulmonata, Bradybaenidae). Molluscan Research 28: 171-174.

Cowie RH (2013) Pathways for transmission of angiostrongyliasis and the risk of disease associated with them. Hawai'i Journal of Medicine \& Public Health 72 (6, Supplement 2): 70-74.

Cowie RH, Robinson DG (2003) Pathways of introduction of nonindigenous land and freshwater snails and slugs. In: Ruiz GM, Carlton JT (Eds) Invasive species: vectors and management strategies. Island Press, Washington, DC, 93-122.

Cowie RH, Dillon Jr RT, Robinson DG, Smith JW (2009) Alien nonmarine snails and slugs of priority quarantine importance in the United States: a preliminary risk assessment. American Malacological Bulletin 27: 113-132. https://doi.org/10.4003/006.027.0210

De Winter AJ, Cremers HJWM, Soes DM (2009) The Asian tramp snail Bradybaena similaris in a tropical greenhouse in Arnhem, The Netherlands. Basteria 73: 61-64.

d'Orbigny A (1835) Synopsis terrestrium et fluviatilium molluscorum, in suo per Americam meridionalem itinere, ab A. d'Orbigny, collectorum. Magasin de Zoologie, d'Anatomie Comparée et de Palaeontologie 5: 1-44.

d'Orbigny A (1838) Tome 5, Partie 3, Mollusques. In: Bertrand CP (Ed) Voyage dans l'Amérique Méridionale (le Brésil, la République Orientale de l'Uruguay, la République Argentine, la Patagonie, la République du Chili, la République de Bolivia, la République du Perou), exécuté pendant les années 1826, 1827, 1828, 1829, 1830, 1831, 1832 et 1833. Chez V.e Levrault, Strasbourg, $185-376$.

Doering A (1874 [1875]) Apuntes sobre la fauna de moluscos de la República Argentina (segunda parte). Boletín de la Academia Nacional de Ciencias Exactas en Córdova 1: 424-457.

Drahg F (1999) Primera cita de Bradybaena similaris (Férussac, 1821) (Mollusca: Gastropoda: Pulmonata) en Argentina. Acta Zoológica Lilloana 45: 149-150.

Gordillo S, Bayer MS, Boretto GM, Burella S, Carrizo M, Darrigran G, De Francesco C, Druetta HS, Gómez CE, Pizá J, Strelin JA, Tamburi N (2013) Brevario malacológico cordobés: descubriendo los bivalvos y caracoles de la provincia de Córdoba. Saya Ediciones, Córdoba, 128 pp.

Gutiérrez Gregoric DE, Núñez V, Vogler RE, Beltramino AA, Rumi A (2013a) Gasterópodos terrestres de la provincia de Misiones, Argentina. Revista de Biología Tropical 61: 1759-1768. https:// doi.org/10.15517/rbt.v61i4.12849

Gutiérrez Gregoric DE, Beltramino AA, Vogler RE, Cuezzo MG, Núñez V, Gomes SR, Virgillito M, Miquel SE (2013b) First records of four exotic slugs in Argentina. American Malacological Bulletin 31: 245-256. https://doi.org/10.4003/006.031.0204 
Gutiérrez Gregoric DE, Betramino AA, Vogler RE, Rumi AA (2013c) Expansión del rango de distribución de Achatina fulica Bowdich, 1822 (Gastropoda) en la Argentina y su concordancia con modelos predictivos. Amici Molluscarum 21: 17-21.

Hall TA (1999) BioEdit: a user-friendly biological sequence alignment editor and analysis program for Windows 95/98/ NT. Nucleic Acids Symposium Series 41: 95-98.

Hugall AF, Stanisic J (2011) Beyond the prolegomenon: a molecular phylogeny of the Australian camaenid land snail radiation. Zoological Journal of the Linnean Society 161: 531-572. https://doi. org/10.1111/j.1096-3642.2010.00644.x

Komai T, Emura S (1955) A study of population genetics on the polymorphic land snail Bradybaena similaris. Evolution 9: 400-418. https://doi.org/10.1111/j.1558-5646.1955.tb01550.x

Köhler F, Criscione F (2013) Plio-Pleistocene out-of-Australia dispersal in a camaenid land snail. Journal of Biogeography 40: 19711982. https://doi.org/10.1111/jbi.12147

Matamoros M (2014) Los moluscos fitófagos en la agricultura cubana. Agricultura Orgánica 20: 9-13.

Miquel SE, Tablado A, Sodor A (2007) Curaduría en la Colección Nacional de Invertebrados de Argentina: aportes a la biodiversidad y biogeografía de gasterópodos terrestres argentinos. Comunicaciones de la Sociedad Malacológica del Uruguay 9: 113-115.

Neck RW (1976) Adventive land snails in the Brownsville, Texas area. The Southwestern Naturalist 21: 133-135. https://doi.org/10. $2307 / 3670337$

Ohlweiler FP, Takahashi FY, Guimarães MCA, Gomes SR, Kawano T (2010) Manual de gastrópodes límnicos e terrestres do estado de São Paulo associados ás helmintoses. Redes Editora, Porto Alegre, $224 \mathrm{pp}$.

Picoral M, Thomé JW (1989) Sobre a anatomia do sistema genital de Bradybaena similaris (Férussac, 1821) (Pulmonata, Stylommatophora, Bradybaenidae) ocorrentes em Porto Alegre, estado do Rio Grande do Sul, Brasil. Memórias do Instituto Oswaldo Cruz 84: 435-439. https://doi.org/10.1590/S0074-02761989000800077

Ramirez J, Ramírez R (2010) Analysis of the secondary structure of mitochondrial LSU rRNA of Peruvian land snails (Orthalicidae: Gastropoda). Revista Peruana de Biología 17: 53-57. https://doi. org/10.15381/rpb.v17i1.51

Reyna PB, Gordillo S, Morán GA (2018) Visitantes sin invitación: moluscos exóticos de la Provincia de Córdoba (Argentina). Revista Facultad de Ciencias Exactas, Físicas y Naturales 5: 71-80.

Robinson DG, Hollingsworth RG (2009) Survey of slug and snail pests on subsistence and garden crops in the islands of the American Pacific: Guam, and the Northern Mariana Islands; the Federated States of Micronesia; and American Samoa, with special reference to Samoa. Unpublished U.S. Department of Agriculture project report, $15 \mathrm{pp}$.

Rumi A, Sánchez J, Ferrando NS (2010) Theba pisana (Müller, 1774) (Gastropoda, Helicidae) and other alien land molluscs species in Argentina. Biological Invasions 12: 2985-2990. https://doi. org/10.1007/s10530-010-9715-x

Schileyko AA (2011) Check-list of land pulmonate molluses of Vietnam (Gastropoda: Stylommatophora). Ruthenica 21: 1-68.

Sei M, Robinson DG, Geneva AJ, Rosenberg G (2017) Doubled helix: Sagdoidea is the overlooked sister group of Helicoidea (Mollusca: Gastropoda: Pulmonata). Biological Journal of the Linnean Society 122: 697-728. https://doi.org/10.1093/biolinnean/blx082

Seki K, Wiwegweaw A, Asami T (2008) Fluorescent pigment distinguishes between sibling snail species. Zoological Science 25: 1212-1219. https://doi.org/10.2108/zsj.25.1212

Serniotti EN, Guzmán LB, Beltramino AA, Vogler RE, Rumi A, Peso JG (2019) New distributional records of the exotic land snail Bradybaena similaris (Férussac, 1822) (Gastropoda, Bradybaenidae) in Argentina. BioInvasions Records 8: 301-313. https://doi. org/10.3391/bir.2019.8.2.12

Virgillito M (2012) Panorama de los gastrópodos terrestres exóticos en la Argentina (Gastropoda Pulmonata Stylommatophora). Licenciate thesis, Universidad de Buenos Aires, Buenos Aires, 101 pp.

Virgillito M, Miquel SE (2013) New records of exotic land snails and slugs in Argentina. Revista del Museo Argentino de Ciencias Naturales 15: 295-303. https://doi.org/10.22179/REVMACN.15.186

Wu M (2004) Preliminary phylogenetic study of Bradybaenidae (Gastropoda: Stylommatophora: Helicoidea). Malacologia 46: 79-125.

Wu M, Asami T (2018) Taxonomical notes on Chinese camaenids with description of three new species (Gastropoda: Pulmonata). Molluscan Research 38: 137-148. https://doi.org/10.1080/13235818.2 017.1380145 